\title{
Political Identity, Decision-Making and Communication in the Age of Digital Media: A Case Study on the 2016 US Elections
}

\author{
Alexandru-Vasile SAVA \\ Department of Philosophy, Faculty of History and Philosophy, \\ Babeș-Bolyai University, Cluj-Napoca \\ E-mail: alexandru_vasile_s@yahoo.ro
}

\begin{abstract}
With the result of the USA presidential election in view, we can finally gain some clarity on the events that have unfolded over the past year. We have seen the rise in the polls of two outsiders in the primary elections of both political parties, one of them successfully winning his party's nomination and the general election. In this paper I will discuss these phenomena focusing on the following lines of questioning: how these campaigns have coordinated on-the-ground activism with online communication in order to gather support, how online discourse has shaped and affected the content of these messages and the decision-making process of voting citizens, how the candidates' processing through media helped produce their political identity and electoral bases, and what are the circumstances that have led to the peculiarities of this election cycle. In order to do this, I will use the tools provided by poststructuralist and critical theory analysis of the public sphere, mass-media and the modern construction of identity, all in relation to the structure of the modern democratic state.
\end{abstract}

Keywords: Democratic participation; post-truth; institutions; social media; poststructuralism.

Acknowledgments: This research was supported by a grant from the project POSDRU/187/1.5/S/155383. 


\section{References}

1. Adorno, T. (1991). The Culture Industry: Selected Essays on Mass Culture. New York \& London: Routledge.

2. Allcott, H., Gentzkow, M. (2017). Social Media and Fake News in the 2016 Election. Working Paper 23089 of the National Bureau of Economic Research. January, 2017. Cambridge, MA. Retrieved from http://www.nber.org/papers/w23089.

3. Althusser, L. (1971). Lenin and Philosophy, and other essays. New York \& London: Monthly Review Press.

4. Appel, H. (2014). Occupy Wall Street and the economic imagination. Cultural Anthropology, 29(4), 602-625.

5. Aragón, P., Volkovich, Y., Laniado, D., \& Kaltenbrunner, A. (2016). When a Movement Becomes a Party: Computational Assessment of New Forms of Political Organization in Social Media In ICWSM. Retrieved from http://www.dtic.upf. edu/ akalten/aragon_etal2016ICWSM.pdf

6. Banda, K.K., Carsey, T.M. (2016). Primary election candidates change their campaign strategies in response to both their current and (potential) future opponents. London School of Economics Blog, 2016. Retrieved from http://eprints.lse.ac.uk/68744/1/ blogs.lse.ac.uk-Primary\%20election\%20candidates\%20change\%20their\%20cam paign $\% 20$ strategies $\% 20 \mathrm{in} \% 20$ response $\% 20$ to $\% 20$ both $\% 20$ their $\% 20$ current $\% 20$ and\%20po.pdf.

7. Bessi, A., Ferrara, E. (2016). Social bots distort the 2016 US Presidential election online discussion. First Monday, 21(11). Retrieved from http://journals.uic.edu/ojs/ index.php/fm/article/view/7090/5653. 
8. Bishop, B. (2009). The big sort: Why the clustering of like-minded America is tearing us apart. Boston: Houghton-Mifflin Harcourt.

9. Chadwick, A., Stromer-Galley, J. (2016). Digital media, power, and democracy in parties and election campaigns: Party decline or party renewal?. The International Journal of Press/Politics, 21(3), 283-293.

10. Colleuori, S. “Fox News has given Donald Trump nearly $\$ 30$ million in free airtime during the Presidential Campaign." Media Matters for America, January 12, 2016. Retrieved from https://mediamatters.org/blog/2016/01/12/fox-news-has-given-don ald-trump-nearly-30-milli/207912.

11. Debord, G. (1995) The Society of the Spectacle. New York: Zone Books.

12. Deleuze, G. Guattari, F. (1987). A thousand plateaus: capitalism and schizophrenia volume 2. Minneapolis: University of Minnesota Press.

13. Deleuze, G., Guattari F. (1983). Anti-Oedipus. Capitalism and Schizophrenia volume 1. Minneapolis: University of Minnesota Press.

14. Dovere, E.I. "How Clinton lost Michigan - and blew the election". Politico, December 14, 2016. Retrieved from http://www.politico.com/story/2016/12/michiganhillary-clinton-trump-232547.

15. Fenton, N. (2016). The internet and radical politics In Curran, J., Fenton, N., Freedman, D. (Eds.), Misunderstanding the internet (149-176). London: Routledge.

16. Galloway, A.R. (2004). Protocol: How Control Exists After Decentralization. Cambridge, MA: MIT Press.

17. Goad, J. (1998). The Redneck Manifesto: How Hillbillies, Hicks, and White Trash Became America's Scapegoats. New York: Simon \& Schuster.

18. Green, S. et al. (2016). Brexit Referendum: first reactions from anthropology. Social Anthropology 24(4), 478-502.

19. Greenwood, S., Perrin, A., Duggan, M. (2016). Social Media Update 2016: Facebook usge and engagement is on the rise, while adoption of other platforms holds steady. Pew Research Center Report, November 11, 2016. Retrieved from http://www. pewinternet.org/2016/11/11/social-media-update-2016.

20. Heaney, M.T. (2016). Bernie Sanders and the Occupy Wall Street Wing of the Democratic Party. Working Paper. Retrieved from http://sites.lsa.umich.edu/mheaney/ wp-content/uploads/sites/38/2016/06/Bernie_Sanders_and_Occupy_Wall_ Street_2016-06-02.pdf.

21. Horkheimer, M., Adorno, T.W. (2002). Dialectic of Enlightenment: Philosophical Fragments. Stanford: Stanford University Press.

22. Huber, P. (1995). A short history of Redneck: The fashioning of a southern white masculine identity. Southern Cultures, 1(2), 145-166.

23. Ignatiev, N. (1995). How the Irish became White. New York \& London: Routledge.

24. Inglehart, R., Norris, P. (2016). Trump, Brexit, and the rise of Populism: Economic havenots and cultural backlash. Working Paper. Accessed at http://wotantue.us/TrumpBrexit-Populism.pdf 
25. Kellner, D. (2016) American Nightmare: Donald Trump, Media Spectacle, and Authoritarian Populism. Rotterdam: Springer.

26. Klug, A., Rees, E., Schneider, J. (2016). Momentum: a new kind of politics. Renewal: a Journal of Labour Politics 24(2), 36-44.

27. Kriesi, H. (2016). Mobilization of protest in the age of austerity In Ancelovici, M., Dufour, P, Nez, H. (Eds.), Street politics in the age of austerity: from the indignados to occupy (67-90). Amsterdam: Amsterdam University Press.

28. Layman, G.C. (1999). "Culture Wars" in the American Party System: Religious and Cultural Change among Partisan Activists Since 1972. American Politics Quarterly, 27(1), 89-121.

29. Lieven, A. (2016). Clinton and Trump: Two Faces of American Nationalism. Survival, 58(5), 7-22.

30. McGann, A.J., Smith, C.A., Latner, M., Keena, A. (2016). Gerrymandering in America: The House of Representatives, the Supreme Court, and the Future of Popular Sovereignty. New York, NY: Cambridge University Press.

31. Pham, V.N. (2015). Our foreign president Barack Obama: The racial logics of birther discourses. Journal of International and Intercultural Communication, 8(2), 86-107.

32. Phillip, A. Wagner, J. Gearan, A. "A series of strategic mistakes likely sealed Clinton's fate". Washington Post, November 12, 2016. Retrieved from https://www. washingtonpost.com/politics/a-series-of-strategic-mistakes-likely-sealed-clintonsfate/2016/11/11/82f3fcc0-a840-11e6-ba59-a7d93165c6d4_story.html?utm_term=. baa47dc94989.

33. Putnam, R.D. (2000). Bowling Alone: The Collapse and Revival of American Community. New York: Simon \& Schuster.

34. Rohlinger, D.A., et al. (2015). Constricting boundaries: collective identity in the tea party movement. In Naples, N., Bickham-Mendez, J. (Eds.), Border politics, globalization and social movements (177-205). New York: New York University Press.

35. Rothwell, J.T., Diego-Rosell, P. (2016). Explaining nationalist political views: The case of Donald Trump. Working Paper. Retrieved from http://pelg.ucsd.edu/2.rothwell_2016.pdf.

36. Statista. (2016). Statistics and facts about social media usage. Retrieved from www. statista.com/topics/1164/social-networks.

37. Tufekci, Z. (2014). Engineering the public: Big data, surveillance and computational politics. First Monday, 19(7). Retrieved from http://firstmonday.org/article/ view/4901/4097.

38. Vance, J.D. (2016). Hillbilly elegy: A memoir of a family and culture in crisis. London: HarperCollins.

39. Williams, C.B., Gulati, G.J. (2008). What is a social network worth? Facebook and vote share in the 2008 presidential primaries. Paper presented at the 2008 Annual Meeting of the American Political Science Association. Retrieved from 
http://195.130.87.21:8080/dspace/bitstream/123456789/1021/1/What\%20is\%20a\%20 social\%20network $\% 20$ worth $\% 20$ Facebook $\% 20$ and $\% 20$ vote $\% 20$ share $\% 20$ in $\% 20$ the $\% 202008 \% 20$ presidential\%20primaries.pdf

40. Wray, M. (2006). Not quite white: White trash and the boundaries of whiteness. Durham, NC: Duke University Press. 